\title{
Somatokognitiv behandling ved kroniske underlivssmerter
}

\begin{abstract}
Somatokognitiv terapi har viste god effekt ved behandling av kroniske underlivssmerter hos kvinner. Vi mener denne behandlingsformen bør prøves ut ved flere gynekologiske avdelinger.
\end{abstract}

Engelsk oversettelse av hele artikkelen på www.tidsskriftet.no

Langvarige underlivssmerter er en vanlig årsak til funksjonsnedsettelse og sykmelding hos kvinner $(1,2)$. Begrepet brukes om smerter som persisterer i mer enn seks måneder i nedre del av abdomen og i det lille bekken. Tilstanden kan skyldes sykdom i flere organsystemer, bl.a. peritoneum, gastrointestinaltractus og urogenitalsystemet, men i mange tilfeller finner man ingen spesifikke patologiske forandringer ved gynekologisk undersøkelse eller laparoskopi (2). Smerter som oppstår kun rundt menstruasjon (dysmenoré) eller ved samleie (dyspareuni) er ekskludert fra definisjonen. Tilstanden kan føre til betydelig funksjonshemning.

\section{Somatokognitiv behandling}

Vi har utviklet en ny kroppsorientert terapiform som vi har kalt somatokognitiv behandling. Dette er en kortvarig terapiform konsentrert om de foreliggende sym-
- Pasienten gjennomgår sine erfaringer siden siste terapitime

- Pasienten lærer nye aktive bevegelser i gradvis progresjon, med enkle bevegelser som skal integreres i dagliglivets aktiviteter, og ikke drives som et eget treningsprogram.

- Gjennomgang av nytt hjemmearbeid som skal utføres i daglige bevegelser frem til neste terapitime

Alliansen mellom pasient og terapeut er svært viktig, som i alle former for terapi (6). Det er vist at terapeutisk allianse er positivt assosiert med terapieffekt (7).

\section{Egne erfaringer}

Vi gjennomførte en randomisert studie med 40 pasienter med kroniske underlivssmerter. Pasientene hadde gjennomgått til sammen 72 kirurgiske inngrep i abdomen, bl.a. eksplorative inngrep, hysterektomi

\section{«Målet for behandlingen er at pasienten skal oppnå ny kroppslig erkjennelse gjennom en utforskende tilnærming med funksjonelle mål knyttet til dagliglivets funksjoner»}

ptomer uavhengig av etiologi, som en hybrid av fysioterapi etter mensendiecktradisjonen og kognitiv terapi ad modum Aaron Beck (3).

Målet for behandlingen er at pasienten skal oppnå ny kroppslig erkjennelse gjennom en utforskende tilnærming med funksjonelle mål knyttet til dagliglivets funksjoner. Etter hvert som behandlingen utvikler seg, kan det åpnes opp for undertrykte følelser. Dette er ikke hovedmålet med behandlingen, men følelsene skal rommes $i$ terapien på en empatisk og dialektisk måte. Hovedfokus ligger på å få nye erfaringer gjennom kroppen, flytte søkelyset fra tanker knyttet til smerte, angst og depresjon etc., til funksjon, og restrukturering av dysfunksjonelle kognitive schemata, gjennom kroppslig utforskning og samtale (4).

Som i kognitiv terapi $(3,5)$ er behandlingssekvensen trefaset: og ekstirpasjon av adnexae, uten tilfredsstillende effekt $(1,8)$. Det kunne ikke påvises spesifikk somatisk etiologi. Ved fysisk funksjonstest (standardisert mensendiecktest, SMT) hadde kvinnene store avvik vedrørende holdning, bevegelse/koordinasjon, gange, sittestilling og respirasjon, økt tensjon og redusert elastisitet av en rekke muskelgrupper og økt psykisk symptombelastning $(1,4)$. Tilstanden ble diagnostisert som persisterende somatoform smertelidelse (ICD-10 F45.4).

Kvinnene ble randomisert til vanlig gynekologisk veiledning med eller uten en ukentlig sesjon på 60 minutter med somatokognitiv terapi over 12 uker. Etter behandlingen hadde kvinnene i behandlingsgruppen $41 \%$ bedre VAS-skår og $63 \%$ bedre respirasjonsskår enn kvinnene som kun mottok veiledning (1). Ved oppfølging ett år etter behandlingsstart hadde frem- gangen fortsatt, og behandlingsgruppen hadde nå $53 \%$ bedre skår for smerte og $86 \%$ bedre skår for respirasjon (8). De hadde også bedring av skår for angst, depresjon og mestring (målt ved GHQ-30). Fortsatt bedring etter avsluttet terapi kan forklares ved at kvinnene nå hadde fått nye erfaringer og metoder for å mestre kroppslige og kognitive utfordringer i dagliglivet, metoder som de selv kunne anvende uavhengig av terapeuten $(1,4)$.

\section{Anbefalinger}

I en kommentar fra American Journal of Obstetrics and Gynecology anføres det at standardisert mensendiecktest kan benyttes til å evaluere kandidater for somatokognitiv behandling, og at somatokognitiv tilnærming kan anvendes på pasienter med langvarig urogenital- og muskel- og skjelettlidelser (8). Vi anbefaler norske gynekologiske avdelinger å utvikle behandlingsprogrammer for pasienter med langvarige underlivssmerter som omfatter en somatokognitiv tilnæring til bevegelsesanalyse og terapi. Der et slikt program ikke er tilgjengelig, kan pasienten henvises videre.

Somatokognitiv terapi har vist god effekt ved behandling av kroniske underlivssmerter hos kvinner. Tilnærmingen har i pilotstudier vist lovende resultater også ved langvarige ryggsmerter, brystsmerter, nakke-/skuldersmerter, generalisert smertelidelse, irritabel tarm-syndrom og smerter i vulvae/vestibulum. Vi mener det er viktig at norske gynekologer er kjent med somatokognitiv behandling, og at behandlingen kan prøves ut ved flere gynekologiske avdelinger.

\section{Tor S. Haugstad}

thaugstad@c2i.net

Høgskolen i Oslo og Akershus og

Sunnaas sykehus

Gro Killi Haugstad

Høgskolen i Oslo og Akershus og

Oslo universitetssykehus

Unni M. Kirste

Kvinneklinikken

Akershus universitetssykehus

\section{Rolf Kirschner}

Kvinne- og barneklinikken

Oslo universitetssykehus

Elin Håkonsen

Høgskolen i Oslo og Akershus 
Tor S. Haugstad (f. 1951) er spesialist i nevrologi, med doktorgrad fra Universitet i Oslo innen nevrobiologi og har forskningserfaring innen nevropsykiatri. Han er overlege og forskningskoordinator ved Sunnaas sykehus og professor ved Høgskolen i Oslo og Akershus. Ingen oppgitte interessekonflikter.

Gro Killi Haugstad (f.1957) er førsteamanuensis ph.d. ved Institutt for fysioterapi, Høgskolen i Oslo og Akershus og har bistilling ved Oslo universitetssykehus, Rikshospitalet som spesialfysioterapeut og forsker ved Avdeling for nevropsykiatri og psykosomatisk medisin. Ingen oppgitte interessekonflikter.

Unni Kirste (f.1948) er spesialist i fødselshjelp og kvinnesykdommer med spesialkompetanse i viscerale smertesyndromer i bekkenet. Hun er overlege ved Smertesenteret, St. Olavs hospital og ved Kvinneklinikken, Akershus universitetssykehus. Hun er leder i Norsk forening for smertemedisin og styremedlem i Norsk smerteforening.

Ingen oppgitte interessekonflikter.

Rolf Kirschner (f. 1946) er spesialist i fødselshjelp og kvinnesykdommer og seksjonsoverlege ved Kvinne- og barnklinikken, Oslo universitetssykehus.

Ingen oppgitte interessekonflikter.

Elin Håkonsen (f. 1955) er høyskolelektor ved Institutt for fysioterapi, Høgskolen i Oslo og Akershus.

Ingen oppgitte interessekonflikter.

\section{Litteratur}

1. Haugstad GK, Haugstad TS, Kirste UM et al. Mensendieck somatocognitive therapy as treatment approach to chronic pelvic pain: results of a randomized controlled intervention study. Am J Obstet Gynecol 2006; 194: 1303-10.

2. Zondervan KT. The community prevalence of chro nic pelvic pain in women and associated illness behavior. Br J Gen Pract 2001; 51: 541 -7.

3. Beck AT. Cognitive therapy and the emotional disorders. New York: International Universities Press, 1976.

4. Haugstad GK, Kirste UM, Leganger S et al. Somatocognitive therapy in the management of chronic gynaecological pain. A review of the historical background and results of a current approach. Scand J Pain 2011; 2: 124-9.

5. Winterowd C, Beck AT, Gruener D Cognitive therapy with chronic pain patients. New York: Springer 2003.

6. Bordin ES. The generalizability of the psychoanalytic concept of the working alliance. Psychother Theor Res Pract 1979: 16: 252-6.

7. Hall AM, Ferreira H, Maher CG et al. The influence of the therapist-patient relationship on treatment outcome in physical rehabilitation: a systematic review. Phys Ther 2010; 90: 1099-110.

8. Haugstad GK, Haugstad TS, Kirste UM et al. Continuing improvement of chronic pelvic pain in women after short-term Mensendieck somatocognitive therapy. Am J Obstet Gynecol 2008; 199 615.e1-8.

Mottatt 30.11. 2011, første revisjon innsendt 4.12. 2011, godkjent 22.12. 2011. Medisinsk redaktør Petter Gjersvik. 